\title{
Influenza A(H1N1)pdm09 virus exhibiting enhanced cross-resistance to oseltamivir and peramivir due to a dual H275Y/G147R substitution, Japan, March 2016
}

E Takashita ${ }^{1}$, S Fujisaki ${ }^{1}$, M Shirakura ${ }^{1}$, K Nakamura ${ }^{1}$, N Kishida ${ }^{1}$, T Kuwahara ${ }^{1}$, Y Shimazu ${ }^{2}$, T Shimomura ${ }^{3}$, S Watanabe ${ }^{1}$, T Odagiri ${ }^{1}$, The Influenza Virus Surveillance Group of Japan 4

1. Influenza Virus Research Center, National Institute of Infectious Diseases, Tokyo, Japan

2. Center for Public Health and Environment, Hiroshima Prefectural Technology Research Institute, Hiroshima, Japan

3. Hiroshima Nishi Medical Center, Hiroshima, Japan

4. The members of the group are listed at the end of the article

Correspondence: Takato Odagiri (todagiri@nih.go.jp)

Citation style for this article:

Takashita E, Fujisaki S, Shirakura M, Nakamura K, Kishida N, Kuwahara T, Shimazu Y, Shimomura T, Watanabe S, Odagiri T, The Influenza Virus Surveillance Group of Japan. Influenza A(H1N1)pdmog virus exhibiting enhanced cross-resistance to oseltamivir and peramivir due to a dual $\mathrm{H}_{275} \mathrm{Y} / \mathrm{G} 147 \mathrm{R}$ substitution, Japan, March 2016. Euro Surveill. 2016;21(24):pii=30258. DOI: http://dx.doi.org/10.2807/1560-7917. ES.2016.21.24.30258

An influenza $A\left(\mathrm{H}_{1} \mathrm{~N}_{1}\right)$ pdmog virus carrying a $\mathrm{G}_{147} \mathrm{R}$ substitution in combination with an $\mathrm{H} 275 \mathrm{Y}$ substitution in the neuraminidase protein, which confers cross-resistance to oseltamivir and peramivir, was detected from an immunocompromised inpatient in Japan, March 2016. This dual H275Y/G147R mutant virus exhibited enhanced cross-resistance to both drugs compared with the single $\mathrm{H}_{275} \mathrm{Y}$ mutant virus and reduced susceptibility to zanamivir, although it showed normal inhibition by laninamivir.

\section{Detection of a dual H275Y/G147R mutant influenza $A(H 1 N 1) p d m 09$ virus}

In the context of our nationwide monitoring for antiviral-resistant viruses, we previously reported that a large community cluster of influenza $\mathrm{A}\left(\mathrm{H}_{1} \mathrm{~N}_{1}\right)$ pdmo9 virus exhibiting cross-resistance to oseltamivir and peramivir had occurred in Hokkaido, Japan between November 2013 and February 2014 [1,2]. Of a total of $2,531 \mathrm{~A}\left(\mathrm{H}_{1} \mathrm{~N}_{1}\right)$ pdmog viruses investigated in the 2013/14 influenza season, 105 (4.1\%) were shown to harbour the $\mathrm{H}_{275} \mathrm{Y}$ substitution in the neuraminidase (NA) protein. In the 2015/16 season (Figure 1), we screened 1,938 $A\left(\mathrm{H}_{1} \mathrm{~N}_{1}\right)$ pdmog viruses by allelic discrimination [3] and detected 39 (2.0\%) H275Y mutant viruses.

No epidemiological links were identified among the patients infected with the $\mathrm{H}_{275} \mathrm{Y}$ mutant viruses except for five nosocomial infections. Among 34 sporadic cases, 11 (32\%) cases had no exposure to NA inhibitors before the specimen collection. This is consistent with our previous study that 19 (32\%) of 59 sporadic cases had no exposure to NA inhibitors in the $2013 / 14$ season [2]. One $\mathrm{H}_{275} \mathrm{Y}$ mutant virus with an additional G147R substitution in the NA protein was detected from a sporadic case treated with peramivir in March 2016. Both substitutions were confirmed in the corresponding clinical specimen. Deep sequencing analysis of the specimen using MiSeq (Illumina, California, United States) revealed that the $\mathrm{G} 147 \mathrm{R}$ substitution was detected in $21 \%$ of mixed sequence populations with $147 \mathrm{G}$ wild type, in contrast to $\mathrm{H}_{2} 75 \mathrm{Y}$, which was detected at a rate of $100 \%$. The results suggested that the $\mathrm{H}_{2} 75 \mathrm{Y}$ mutant virus had acquired the additional G147R substitution in the patient during peramivir administration. The $\mathrm{NA} \mathrm{H} 275 \mathrm{Y}$ mutation of the $\mathrm{A}\left(\mathrm{H}_{1} \mathrm{~N}_{1}\right)$ pdmog and the former seasonal $A\left(\mathrm{H}_{1} \mathrm{~N}_{1}\right)$ viruses confers cross-resistance to oseltamivir and peramivir [4] and the NA G147R is linked to slightly reduced susceptibility of the highly pathogenic avian $\mathrm{A}\left(\mathrm{H}_{5} \mathrm{~N}_{1}\right)$ virus to oseltamivir and zanamivir [5]. Searching the EpiFlu Database of the Global Initiative on Sharing All Influenza Data (GISAID) yielded 18,172 $A\left(\mathrm{H}_{1} \mathrm{~N}_{1}\right)$ pdmo9 viruses, of which nine were G147R mutant viruses (Table). No dual H275Y/G147R substitution appears to have been previously reported however.

Clinical course of the patient infected with the dual $\mathrm{H} 275 \mathrm{Y} / \mathrm{G} 147 \mathrm{R}$ mutant virus

The patient, a woman in her early 50 s with malignant lymphoma who was receiving chemotherapy, was hospitalised with myelosuppression in late February 2016. She received prophylaxis with laninamivir $(40 \mathrm{mg})$ on the same day because her husband had been diagnosed as having influenza A virus infection. Three days later, she had onset of illness and tested positive for influenza A. At this time, peramivir was administered intravenously at a dosage of $600 \mathrm{mg}$ daily for three intermittent periods of 5 days because of persistent influenza A virus infection. She developed left lower 


\section{FIGURE 1}

Detection of influenza viruses, September 2015-April

2016 (week 36, 2015-18, 2016) , Japan $(\mathrm{n}=5,778)$

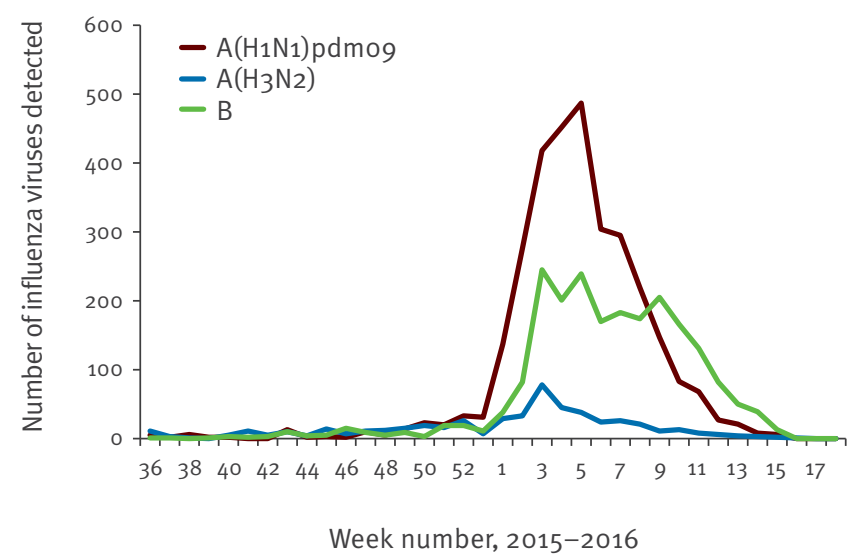

Weekly reports of influenza virus isolation/detection by the National Epidemiological Surveillance of Infectious Diseases.

a Week 36 started on 31 August 2015.

lobe pneumonia 20 days post-disease onset and alveolar haemorrhage 12 days after, but no bacterial pathogens were isolated from sputum or blood samples. She died 5 days later. A nasal swab specimen of the patient was collected only at the end of the second intermittent administration of peramivir and an influenza $\mathrm{A}\left(\mathrm{H}_{1} \mathrm{~N}_{1}\right)$ pdmo9 strain $\mathrm{A} /$ Hiroshima/13/2016 was isolated in Madin-Darby canine kidney (MDCK) cells from the specimen (Table). We could not obtain a specimen from the husband.

\section{Antiviral susceptibility of the dual H275Y/ G147R mutant virus}

After isolation in MDCK cells, A/Hiroshima/13/2016 possessed the $\mathrm{H}_{275} \mathrm{Y}$ and $\mathrm{G} 147 \mathrm{R}$ substitutions in $100 \%$ population, respectively, although the G147R mutation was detected at a rate of $21 \%$ in the specimen. This result indicates that the virus carrying both substitutions had become predominant during MDCK cell culture.

We compared the susceptibilities of the dual $\mathrm{H} 275 \mathrm{Y} /$ G147R mutant virus and single $\mathrm{H} 275 \mathrm{Y}$ mutant viruses isolated during the same influenza season to four NA inhibitors approved in Japan: laninamivir, oseltamivir, peramivir and zanamivir (Figure 2).

Oseltamivir carboxylate, peramivir and zanamivir were purchased from Sequoia Research Products (Pangbourne, UK) and laninamivir was kindly provided by Daiichi Sankyo Co., Ltd. (Tokyo, Japan). The susceptibilities of the viruses to NA inhibitors were determined by fluorescent NA inhibition assay with the NA-Fluor Influenza Neuraminidase Assay Kit (Applied Biosystems, California, United States). Results were expressed as the drug concentrations required to inhibit
NA activity by $50 \%($ IC $)$. To interpret the NA inhibitor susceptibility, we used the World Health Organization criteria, which are based on the fold change of $\mathrm{IC}_{50}$ values compared with the median $\mathrm{IC}_{50}$ values of the same subtype/lineage [6]. For influenza A viruses, normal ( $<10$-fold increase of $I C_{50}$ value), reduced (10-10o-fold increase) or highly reduced ( $>100$-fold increase) inhibition were defined.

The $\mathrm{IC}_{50}$ values of the viruses to laninamivir, oseltamivir, peramivir and zanamivir are shown in Figure 2. The median $\mathrm{IC}_{50}$ values of 19 single $\mathrm{H}_{275} \mathrm{Y}$ mutant viruses to oseltamivir and peramivir were $920-$ and 260 -fold higher, respectively, than those of the 236 wild-type viruses. The dual $\mathrm{H}_{275} \mathrm{Y} / \mathrm{G} 147 \mathrm{R}$ mutant virus exhibited 2,600- and 1,400-fold higher $I C_{50}$ values to oseltamivir and peramivir, respectively, compared with the wild-type viruses. These results indicate that the dual H275Y/G147R mutant virus showed highly reduced inhibition with high increases in oseltamivir and peramivir $\mathrm{IC}_{50}$ values compared with values for the single $\mathrm{H}_{275} \mathrm{Y}$ mutant viruses. Furthermore, the $\mathrm{IC}_{50}$ value of the dual mutant virus to zanamivir was ca fivefold higher than the median $\mathrm{IC}_{50}$ values of the wild type and the single $\mathrm{H} 275 \mathrm{Y}$ mutant viruses, although the dual mutant virus showed normal inhibition by laninamivir.

\section{Discussion}

The first widespread community cluster of the $\mathrm{H}_{275} \mathrm{Y}$ mutant $\mathrm{A}\left(\mathrm{H}_{1} \mathrm{~N}_{1}\right)$ pdmog virus was detected in Newcastle, Australia in 2011 [7]. The $\mathrm{H}_{275} \mathrm{Y}$ substitution in the NA protein would destabilise the mutant virus. However, two additional $\mathrm{V}_{241} \mathrm{l}$ and $\mathrm{N} 369 \mathrm{~K}$ substitutions in the $\mathrm{NA}$ of $\mathrm{H}_{275} \mathrm{Y}$ mutant viruses were reported to increase their replication and transmission fitness, contributing to efficient transmission [8,9]. Almost all recently circulating $\mathrm{A}\left(\mathrm{H}_{1} \mathrm{~N}_{1}\right)$ pdmog viruses possess these permissive substitutions, suggesting an increased risk for $\mathrm{H} 275 \mathrm{Y}$ mutant viruses to emerge and spread globally [10]. Indeed, during the 2013/14 influenza season, the $\mathrm{H} 275 \mathrm{Y}$ mutant viruses from a large community cluster in Hokkaido, Japan carried these permissive substitutions. Following this finding, we subsequently increased nationwide monitoring for the $\mathrm{H}_{275} \mathrm{Y}$ mutant viruses in the 2015/16 season and detected an $\mathrm{H}_{275} \mathrm{Y}$ mutant with $\mathrm{V}_{241}$ and $\mathrm{N}_{3} 69 \mathrm{~K}$ and an additional G147R substitution in the NA protein from an immunocompromised inpatient. The $\mathrm{IC}_{50}$ fold changes of a number of NA inhibitors for the dual $\mathrm{H}_{275} \mathrm{Y} / \mathrm{G} 147 \mathrm{R}$ mutant virus compared with those for the single $\mathrm{H}_{275} \mathrm{Y}$ viruses showed clearly the synergistic effect of this dual substitution (Figure 2).

Hooper et al. reported that the $\mathrm{G} 147 \mathrm{R}$ substitution in the NA protein has been detected in $\mathrm{A}\left(\mathrm{H}_{1} \mathrm{~N}_{1}\right)$ pdmog, in the former seasonal $A\left(\mathrm{H}_{1} \mathrm{~N}_{1}\right)$ as well as in the $\mathrm{A}\left(\mathrm{H}_{5} \mathrm{~N}_{1}\right)$ viruses where it conferred receptor-binding activity to the NA proteins of these viruses, similar to a D151G substitution in the $N A$ of $A\left(\mathrm{H}_{3} \mathrm{~N}_{2}\right)$ viruses $[11,12]$. Phylogenetic analyses suggested that these G147R mutant viruses occurred sporadically in nature, while 


\section{FIGURE 2}

Susceptibility to neuraminidase inhibitors of influenza A(H1N1)pdm09 viruses with H275Y and G147R substitutions detected in Japan, September 2015-April $2016(\mathrm{n}=256)$
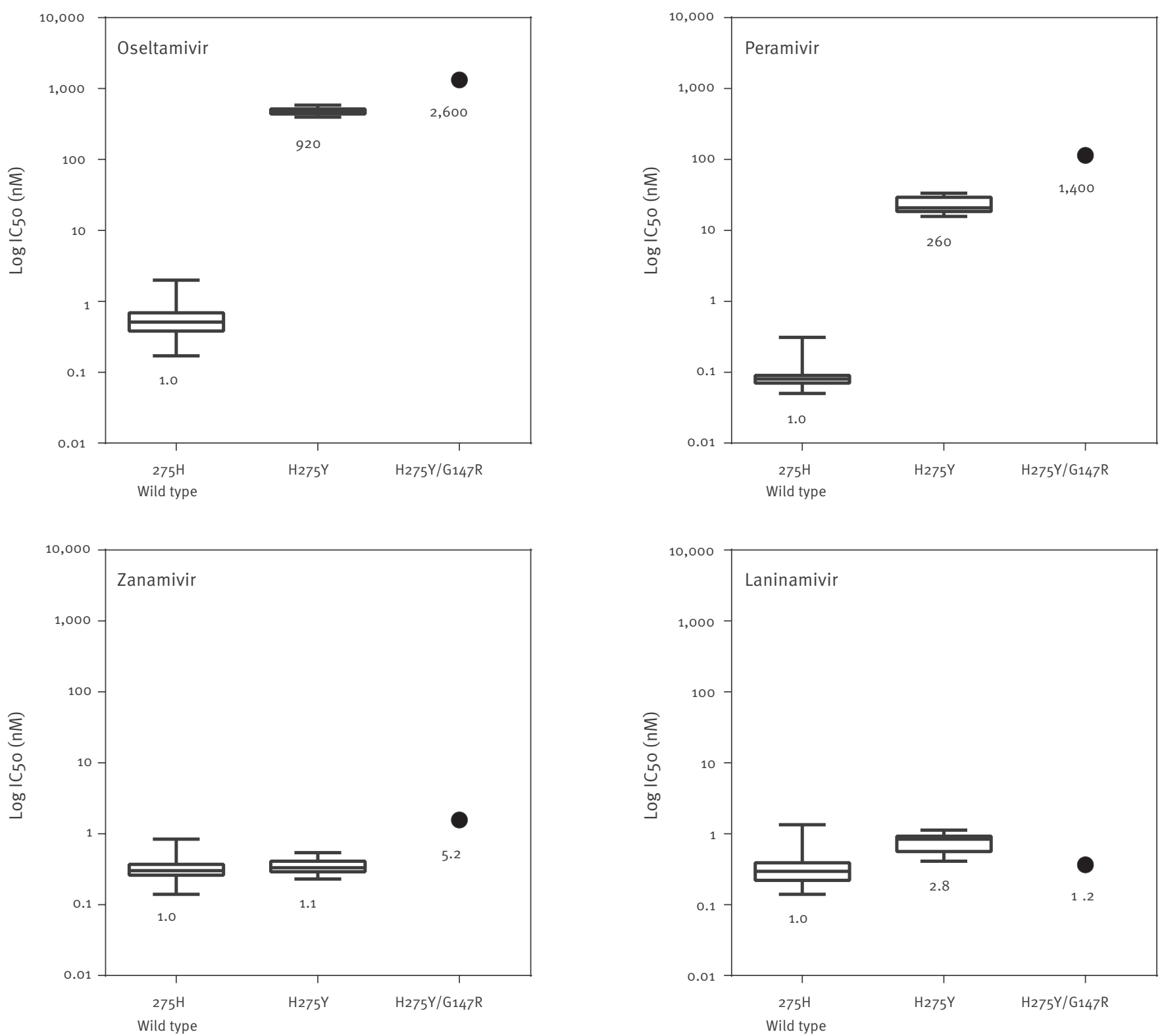

IC 50: $50 \%$ inhibitory concentration.

The IC 50 values of the viruses to laninamivir, oseltamivir, peramivir and zanamivir were determined by fluorescent neuraminidase inhibition assay. Box-and-whisker plots of the IC 50 values (medians and interquartile ranges) are shown. The numbers at the bottom of each box-andwhisker plot indicate the fold change in $\mathrm{IC}_{50}$ values compared with the median $\mathrm{IC}_{50}$ values of $275 \mathrm{H}$ wild-type viruses.

the $\mathrm{D} 151 \mathrm{G}$ substitution emerged during propagation of virus in MDCK cell culture $[11,12]$.

Residue 147 is located in a 150-loop that includes residues 147 to 152 adjacent to the NA active site as shown in Figure 3 [13]. A previous study reported it as having an essential role in the conformation of the 150loop [14]. Our structural analysis of the NA protein of the dual $\mathrm{H}_{275} \mathrm{Y} / \mathrm{G} 147 \mathrm{R}$ mutant virus using Molecular Operating Environment, MOE, (Chemical Computing Group Inc., Quebec, Canada) [15] suggests that the
G147R substitution may alter the stability of the 150loop because the side chain of arginine is larger than that of glycine (Figure 3), negatively affecting the binding affinity to NA inhibitors.

The G147R substitution of $\mathrm{N}_{1} \mathrm{NA}$ has been shown to slightly decrease enzymatic activity but not to affect the viral replication fitness [12]. These results, together with the findings of recent $\mathrm{H}_{2} 75 \mathrm{Y}$ mutant viruses carrying permissive substitutions, $\mathrm{V}_{241} \mathrm{l}$ and $\mathrm{N} 369 \mathrm{~K}$, suggest that the dual $\mathrm{H}_{275} \mathrm{Y} / \mathrm{G} 147 \mathrm{R}$ mutant virus had the 


\section{FIGURE 3}

Three-dimensional structure of the neuraminidase protein of influenza $\mathrm{A}(\mathrm{H} 1 \mathrm{N1}) \mathrm{pdm} 09$ virus with the $\mathrm{H} 275 \mathrm{Y}$ and G147R substitutions

A. $\mathrm{H} 275 \mathrm{Y}$

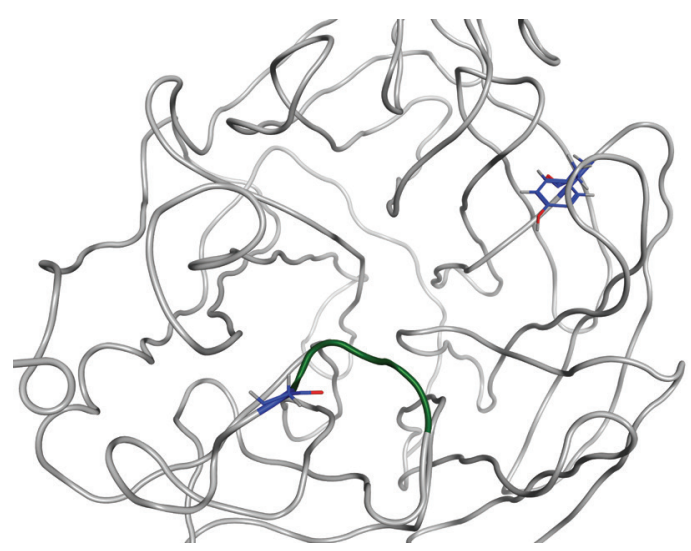

B. $\mathrm{H}_{275} \mathrm{Y} / \mathrm{G} 147 \mathrm{R}$

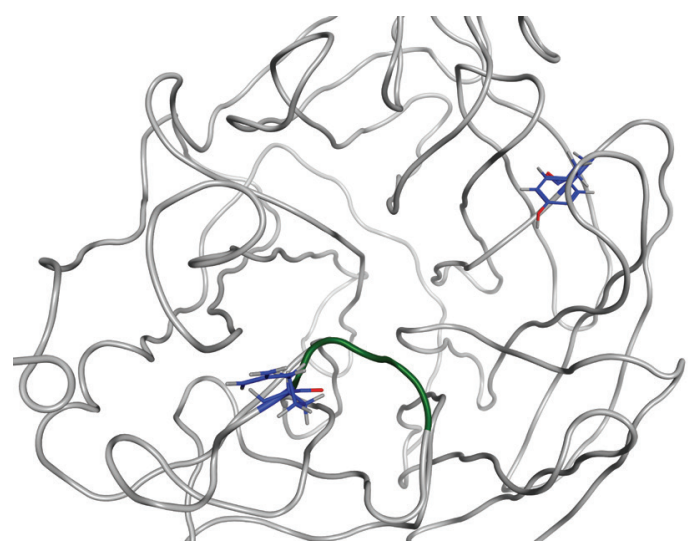

Structure models of the neuraminidase proteins of the single $\mathrm{H}_{275} \mathrm{Y}(\mathrm{A})$ and the dual $\mathrm{H}_{275} \mathrm{Y} / \mathrm{G}_{147} \mathrm{R}(\mathrm{B})$ mutant viruses were constructed by homology modelling. The crystal structure of the $A\left(H_{1} N_{1}\right)$ pdmog neuraminidase protein (PDB ID: $4 B 7 R$ ) was used as the modelling template.

A 150-loop in the neuraminidase protein is shown in green.

potential to replicate efficiently. In this study, we found that the dual $\mathrm{H}_{275} \mathrm{Y} / \mathrm{G}_{147} \mathrm{R}$ mutant virus grew well in cell culture. Furthermore, the patient infected with the dual $\mathrm{H}_{275} \mathrm{Y} / \mathrm{G} 147 \mathrm{R}$ mutant virus developed pneumonia without isolation of bacterial pathogens, suggesting viral pneumonia with this dual mutant virus.

Immunocompromised patients are at great risk for emergence of the antiviral resistant virus because of the selective pressure from prolonged exposure to antiviral drugs [16]. A high rate and prolonged shedding of the $\mathrm{H}_{2} 75 \mathrm{Y}$ mutant $\mathrm{A}\left(\mathrm{H}_{1} \mathrm{~N}_{1}\right)$ pdmog virus in immunocompromised patients treated with oseltamivir and/ or peramivir were reported previously [17]. As a specimen from the husband of the patient was unavailable, we cannot rule out that the patient was infected with a virus readily carrying the $\mathrm{G}_{147} \mathrm{R}$ substitution. Results of this study nevertheless suggest that this substitution likely occurred in the patient during peramivir treatment. On the other hand, whether the $\mathrm{H}_{275} \mathrm{Y}$ mutation had already occurred or not before infection remains unclear. Other additional substitutions, I223R and $\mathrm{S}_{247} \mathrm{~N}$, in the NA protein of $\mathrm{H}_{2} 75 \mathrm{Y}$ mutant $\mathrm{A}\left(\mathrm{H}_{1} \mathrm{~N}_{1}\right)$ pdmog viruses have been reported and showed a synergistic effect with the $\mathrm{H}_{2} 75 \mathrm{Y}$ substitution on the reduction of NA inhibitor susceptibility $[18,19]$. Although the frequencies of these dual substitutions were low, the surveillance of antiviral-resistant viruses should be continued to protect public health and support clinical management, particularly for high risk populations.

\section{The Influenza Virus Surveillance Group of Japan}

The members of the Influenza Virus Surveillance Group of Japan are: Rika Komagome (Hokkaido Institute of Public Health), Asami Ohnishi (Sapporo City Institute of Public Health), Rika Tsutsui (Aomori Prefectural Public Health and Environment Center), Masaki Takahashi (Research Institute for Environmental Sciences and Public Health of Iwate Prefecture), Yuko Suzuki (Miyagi Prefectural Institute of Public Health and Environment), Yu Watanabe (Sendai City Institute of Public Health), Chihiro Shibata (Akita Prefectural Research Center for Public Health and Environment), Yohei Matoba (Yamagata Prefectural Institute of Public Health), Yoshiko Kashiwagi (Fukushima Prefectural Institute of Public Health), Miwako Kato (Niigata Prefectural Institute of Public Health and Environmental Sciences), Kazunari Yamamoto (Niigata City Institute of Public Health and Environment), Ikuko Doi (Ibaraki Prefectural Institute of Public Health), Takako Suzuki (Tochigi Prefectural Institute of Public Health and Environmental Sciences), Shunsuke Kataoka (Utsunomiya City Institute of Public Health and Environment Science), Hiroyuki Tsukagoshi (Gunma Prefectural Institute of Public Health and Environmental Sciences), Noriko Suzuki (Saitama Institute of Public Health), Yuka Uno (Saitama City Institute of Health Science and Research), Noriko Oitate (Chiba Prefectural Institute of Public Health), Wakako Nishikawa (Chiba City Institute of Health and Environment), Sachiko Harada (Tokyo Metropolitan Institute of Public Health), Sumi Watanabe (Kanagawa Prefectural Institute of Public Health), Chiharu Kawakami (Yokohama City Institute of Public Health), Hideaki Shimizu (Kawasaki City Institute of Public Health), Hazime Amano (Yokosuka Institute of Public Health), Sayoko Arakawa (Sagamihara City Institute of Public Health), Masayuki Oonuma (Yamanashi Institute for Public Health), Mami Shimazaki (Nagano Environmental Conservation Research Institute), Yuichiro Okamura (Nagano City Health Center), Yukiko Sakai (Shizuoka Institute of Environment and Hygiene), Nona Shibahara (Shizuoka City Institute of Environmental Sciences and Public Health), Toshihiko Furuta (Hamamatsu City Health Environment Research Center), Masatsugu Obuchi (Toyama Institute of Health), Hiroe Kodama (Ishikawa Prefectural Institute of Public Health and Environmental science), Eiko Hirano (Fukui Prefectural Institute of Public Health and Environmental Science), Masahiro Nishioka (Gifu Prefectural Research Institute for Health and Environmental Sciences), Yoshihiro Yasui (Aichi Prefectural Institute of Public Health), Takuya Yano (Mie Prefecture Health and Environment Research Institute), Hiromi Kodama (Shiga Prefectural Institute of Public Health), Jun Torii (Kyoto Prefectural Institute of Public Health and Environment), Akiko Nagasao (Kyoto City Institute of Health and Environmental Sciences), Satoshi Hiroi (Osaka Prefectural Institute of Public Health), Hideyuki Kubo (Osaka City Institute of Public Health and Environmental Sciences), Kiyoko Uchino (Sakai City Institute of Public Health), Tomohiro 
TABLE

Influenza A(H1N1)pdm09 viruses with G147R substitution submitted to the GISAID's EpiFlu Database

\begin{tabular}{|c|c|c|c|c|c|c|c|}
\hline GISAID Isolate ID & Country & $\begin{array}{l}\text { Collection } \\
\text { date }\end{array}$ & Isolate name & $\begin{array}{l}\text { Originating } \\
\text { laboratory }\end{array}$ & $\begin{array}{l}\text { Submitting } \\
\text { laboratory }\end{array}$ & NA subs & titution \\
\hline EPI_ISL_63723 & Finland & $\begin{array}{c}2009-07- \\
24\end{array}$ & A/Finland/614/2009 & \multicolumn{2}{|c|}{ Other Database Import } & $\mathrm{G}_{147} \mathrm{R}$ & $275 \mathrm{H}$ \\
\hline EPI_ISL_108540 & China & $\begin{array}{l}\text { 2011-01- } \\
08\end{array}$ & A/Tianjinhedong/SWL44/2011 & \multicolumn{2}{|c|}{ Other Database Import } & G147R & $275 \mathrm{H}$ \\
\hline EPI_ISL_123113 & Singapore & $\begin{array}{c}2011-02- \\
09\end{array}$ & A/Singapore/SGHo2/2011 & \multicolumn{2}{|c|}{ Other Database Import } & G147R & $275 \mathrm{H}$ \\
\hline EPI_ISL_98830 & Argentina & $\begin{array}{c}2011-08- \\
05\end{array}$ & A/Argentina/656/2011 & $\begin{array}{l}\text { Instituto Nacional } \\
\text { de Enfermedades } \\
\text { Infecciosas }\end{array}$ & $\begin{array}{l}\text { Centers for Disease } \\
\text { Control and } \\
\text { Prevention }\end{array}$ & G147R & $275 \mathrm{H}$ \\
\hline EPI_ISL_150164 & India & $\begin{array}{c}2013-09- \\
07\end{array}$ & A/India/3743/2013 & $\begin{array}{l}\text { National Institute } \\
\text { of Virology }\end{array}$ & $\begin{array}{l}\text { Centers for Disease } \\
\text { Control and } \\
\text { Prevention }\end{array}$ & G147R & $275 \mathrm{H}$ \\
\hline EPI_ISL_212270 & UK & $\begin{array}{c}2014-03- \\
13\end{array}$ & A/England/354/2014 & $\begin{array}{c}\text { Microbiology } \\
\text { Services Colindale, } \\
\text { Public Health } \\
\text { England }\end{array}$ & \begin{tabular}{|c|} 
Microbiology \\
Services Colindale, \\
Public Health \\
England
\end{tabular} & $\mathrm{G} 147 \mathrm{R}$ & $275 \mathrm{H}$ \\
\hline EPI_ISL_164370 & India & $\begin{array}{c}2014-05- \\
24\end{array}$ & A/India/5964/2014 & $\begin{array}{c}\text { National Institute } \\
\text { of Virology }\end{array}$ & $\begin{array}{l}\text { Centers for Disease } \\
\text { Control and } \\
\text { Prevention }\end{array}$ & $\mathrm{G}_{147 \mathrm{R}}$ & $275 \mathrm{H}$ \\
\hline EPI_ISL_207955 & $\begin{array}{l}\text { United } \\
\text { States }\end{array}$ & $\begin{array}{c}2016-01- \\
01\end{array}$ & A/Wisconsin/02/2016 & $\begin{array}{c}\text { Wisconsin State } \\
\text { Laboratory of } \\
\text { Hygiene }\end{array}$ & $\begin{array}{l}\text { Centers for Disease } \\
\text { Control and } \\
\text { Prevention }\end{array}$ & $\mathrm{G}_{147} \mathrm{R}$ & $275 \mathrm{H}$ \\
\hline EPI_ISL_209086 & $\begin{array}{l}\text { Russian } \\
\text { Federation }\end{array}$ & $\begin{array}{c}2016-01- \\
15\end{array}$ & A/Orenburg/05/2016 & $\begin{array}{l}\text { Information not } \\
\text { available }\end{array}$ & $\begin{array}{c}\text { State Research } \\
\text { Center of Virology } \\
\text { and Biotechnology } \\
\text { Vector }\end{array}$ & G147R & $275 \mathrm{H}$ \\
\hline EPI_ISL_220376 & Japan & $\begin{array}{c}2016-03- \\
11\end{array}$ & A/Hiroshima/13/2016 & $\begin{array}{c}\text { Hiroshima } \\
\text { Prefectural } \\
\text { Technology } \\
\text { Research Institute }\end{array}$ & $\begin{array}{l}\text { National Institute } \\
\text { of Infectious } \\
\text { Diseases }\end{array}$ & G147R & $\mathrm{H} 275 \mathrm{Y}$ \\
\hline
\end{tabular}

GISAID: Global Initiative on Sharing All Influenza Data; NA: neuraminidase.

Oshibe (Hyogo Prefectural Institute of Public Health and Consumer Sciences), Ai Mori (Kobe Institute of Health), Daichi Sugimoto (Nara Prefecture Institute of Health), Yuki Matsui (Wakayama Prefectural Research Center of Environment and Public Health), Hidenobu Ekawa (Wakayama City Institute of Public Health), Nobuyuki Kato (Tottori Prefectural Institute of Public Health and Environmental Science), Tetsuo Mita (Shimane Prefectural Institute of Public Health and Environmental Science), Yasuhiro Matsuoka (Okayama Prefectural Institute for Environmental Science and Public Health), Shinichi Takao (Center for Public Health and Environment, Hiroshima Prefectural Technology Research Institute), Miwako Yamamoto (Hiroshima City Institute of Public Health), Shoichi Toda (Yamaguchi Prefectural Institute of Public Health and Environment), Marina Uramoto (Tokushima Prefectural Public Health, Pharmaceutical and Environmental Sciences Center), Yukari Terajima (Kagawa Prefectural Research Institute for Environmental Sciences and Public Health), Fumi Mizota (Ehime Prefecture Institute of Public Health and Environmental Science), Tae Taniwaki (Kochi Public Health and Sanitation Institute), Yuki Ashizuka (Fukuoka Institute of Health and Environmental Sciences), Hideomi Furukawa (Fukuoka City Institute of Health and Environment), Takashi Kimura (Kitakyushu City Institute of Environmental Sciences), Katsuyuki Ando (Saga Prefectural Institute of Public Health and Pharmaceutical Research), Kana Miura (Nagasaki Prefectural Institute for Environment Research and Public Health), Kenta Yoshioka (Kumamoto Prefectural Institute of Public-Health and Environmental Science), Kaori Nishizawa (Kumamoto City Environmental
Research Center), Miki Kato (Oita Prefectural Institute of Health and Environment), Miho Miura (Miyazaki Prefectural Institute for Public Health and Environment), Yuka Iwamoto (Kagoshima Prefectural Institute for Environmental Research and Public Health), and Kuba Yumani (Okinawa Prefectural Institute of Health and Environment).

\section{Acknowledgements}

We thank Rie Ogawa, Hideka Miura, Hiromi Sugawara, Aya Sato and Miki Akimoto for technical assistance and Drs. Masato Tashiro and Yoko Matsuzaki for fruitful discussions. We acknowledge the authors, originating and submitting laboratories of the sequences from GISAID's EpiFlu Database on which this research is based (see Table). All submitters of data may be contacted directly via the GISAID website www. gisaid.org

This study was supported, in part, by Grant-in-Aid for Emerging and Reemerging Infectious Diseases from the Ministry of Health, Labour and Welfare, Japan and by JSPS KAKENHI grant 26460816.

\section{Conflict of interest}

None declared. 


\section{Authors' contributions}

Designed the analyses: ET, SF, SW, TO. Analysed and interpreted data: ET, SF, MS, KN, NK, TK, YS, TS, SW, TO, The members of the Influenza Virus Surveillance Group of Japan. Drafted the article: ET. Revised the article: SW, TO.

\section{References}

1. Takashita E, Ejima M, Itoh R, Miura M, Ohnishi A, Nishimura $\mathrm{H}$, et al. A community cluster of influenza $A\left(\mathrm{H}_{1} \mathrm{~N}_{1}\right)$ pdmo9 virus exhibiting cross-resistance to oseltamivir and peramivir in Japan, November to December 2013. Euro Surveill. 2014;19(1):20666. DOI: 10.2807/1560-7917.ES2014.19.1.20666 PMID: 24434172

2. Takashita E, Kiso M, Fujisaki S, Yokoyama M, Nakamura K, Shirakura M, et al. Characterization of a large cluster of influenza $A\left(\mathrm{H}_{1} \mathrm{~N}_{1}\right)$ pdmog viruses cross-resistant to oseltamivir and peramivir during the 2013-2014 influenza season in Japan. Antimicrob Agents Chemother. 2015;59(5):2607-17. DOI: 10.1128/AAC.04836-14 PMID: 25691635

3. Nakauchi M, Ujike M, Obuchi M, Takashita E, Takayama I, Ejima $M$, et al. , influenza virus surveillance group of Japan. Rapid discrimination of oseltamivir-resistant $275 \mathrm{Y}$ and -susceptible $275 \mathrm{H}$ substitutions in the neuraminidase gene of pandemic influenza A/H1N1 2009 virus by duplex one-step RT-PCR assay.J Med Virol. 2011;83(7):1121-7. DOI: 10.1002/jmv.22101 PMID: 21567417

4. Takashita E, Fujisaki S, Kishida N, Xu H, Imai M, Tashiro $M$, et al. , Influenza Virus Surveillance Group of Japan. Characterization of neuraminidase inhibitor-resistant influenza $A\left(\mathrm{H}_{1} \mathrm{~N}_{1}\right)$ pdmog viruses isolated in four seasons during pandemic and post-pandemic periods in Japan.Influenza Other Respi Viruses. 2013;7(6):1390-9. DOI: 10.1111/irv.12132 PMID: 23745712

5. Nguyen HT, Nguyen T, Mishin VP, Sleeman K, Balish A, Jones J, et al. Antiviral susceptibility of highly pathogenic avian influenza $A\left(\mathrm{H}_{5} \mathrm{~N}_{1}\right)$ viruses isolated from poultry, Vietnam, 2009-2011. Emerg Infect Dis. 2013;19(12):1963-71. DOI: 10.3201/eid1912.130705 PMID: 24274711

6. Meetings of the WHO working group on surveillance of influenza antiviral susceptibility - Geneva, November 2011 and June 2012. Wkly Epidemiol Rec. 2012;87(39):369-74.PMID: 23061103

7. Hurt AC, Hardie K, Wilson NJ, Deng YM, Osbourn M, Leang SK, et al. Characteristics of a widespread community cluster of $\mathrm{H}_{27} \mathrm{Y}_{\mathrm{Y}}$ oseltamivir-resistant $\mathrm{A}\left(\mathrm{H}_{1} \mathrm{~N}_{1}\right)$ pdmog influenza in Australia. J Infect Dis. 2012;206(2):148-57. DOI: 10.1093/infdis/ jis337 PMID: 22561367

8. Butler L, Hooper KA, Petrie S, Lee R, Maurer-Stroh S, Reh $L$, et al. Estimating the fitness advantage conferred by permissive neuraminidase mutations in recent oseltamivirresistant $A\left(\mathrm{H}_{1} \mathrm{~N}_{1}\right)$ pdmog influenza viruses. PLoS Pathog. 2014;10(4):e1004065. DOI: 10.1371/journal.ppat.1004065 PMID: 24699865

9. Abed Y, Pizzorno A, Bouhy X, Rhéaume C, Boivin G. Impact of potential permissive neuraminidase mutations on viral fitness of the $\mathrm{H}_{2} 75 \mathrm{Y}$ oseltamivir-resistant influenza $\mathrm{A}\left(\mathrm{H}_{1} \mathrm{~N}_{1}\right)$ pdmog virus in vitro, in mice and in ferrets.J Virol. 2014;88(3):1652-8. DOI: 10.1128/JVI.02681-13 PMID: 24257597

10. Takashita E, Meijer A, Lackenby A, Gubareva L, Rebelode-Andrade $H$, Besselaar $T$, et al. Global update on the susceptibility of human influenza viruses to neuraminidase inhibitors, 2013-2014. Antiviral Res. 2015;117:27-38. DOI: 10.1016/j.antiviral.2015.02.003 PMID: 25721488

11. Hooper KA, Bloom JD. A mutant influenza virus that uses an $\mathrm{N} 1$ neuraminidase as the receptor-binding protein.J Virol. 2013;87(23):12531-40. DOI: 10.1128/JVI.01889-13 PMID: 24027333

12. Hooper KA, Crowe JE, Bloom JD. Influenza viruses with receptor-binding $\mathrm{N} 1$ neuraminidases occur sporadically in several lineages and show no attenuation in cell culture or mice.J Virol. 2015;89(7):3737-45. DOI: 10.1128/JVI.00012-15 PMID: 25609803

13. Russell RJ, Haire LF, Stevens DJ, Collins PJ, Lin YP, Blackburn GM, et al. The structure of $\mathrm{H}_{5} \mathrm{~N}_{1}$ avian influenza neuraminidase suggests new opportunities for drug design. Nature. 2006;443(7107):45-9. DOI: 10.1038/nature05114 PMID: 16915235

14. Wu Y, Qin G, Gao F, Liu Y, Vavricka CJ, Qi J, et al. Induced opening of influenza virus neuraminidase N2 150-loop suggests an important role in inhibitor binding. Sci Rep. 2013;3:1551. DOI: 10.1038/srep01551 PMID: 23531861
15. Molecular Operating Environment (MOE). 2013.08; Chemical Computing Group Inc., 1010 Sherbooke St. West, Suite \#910, Montreal, QC, Canada, H3A 2R7, 2016.

16. Hurt AC, Chotpitayasunondh T, Cox NJ, Daniels R, Fry AM, Gubareva LV, et al., WHO Consultation on Pandemic Influenza A ( $\left.\mathrm{H}_{1} \mathrm{~N}_{1}\right) 2009$ Virus Resistance to Antivirals. Antiviral resistance during the 2009 influenza $A H_{1} N_{1}$ pandemic: public health, laboratory, and clinical perspectives. Lancet Infect Dis. 2012;12(3):240-8. DOI: 10.1016/S1473-3099(11)70318-8 PMID: 22186145

17. Renaud C, Boudreault AA, Kuypers J, Lofy KH, Corey L, Boeckh MJ, et al. $\mathrm{H}_{275} \mathrm{Y}$ mutant pandemic ( $\left.\mathrm{H}_{1} \mathrm{~N}_{1}\right) 2009$ virus in immunocompromised patients. Emerg Infect Dis. 2011;17(4):653-60, quiz 765. DOI: 10.3201/eid1704.101429 PMID: 21470455

18. Nguyen HT, Fry AM, Loveless PA, Klimov AI, Gubareva LV. Recovery of a multidrug-resistant strain of pandemic influenza A 2009 ( $\mathrm{H}_{1} \mathrm{~N}_{1}$ ) virus carrying a dual $\mathrm{H}_{275} \mathrm{Y} / \mathrm{I} 223 \mathrm{R}$ mutation from a child after prolonged treatment with oseltamivir.Clin Infect Dis. 2010;51(8):983-4. DOI: 10.1086/656439 PMID: 20858074

19. Hurt AC, Lee RT, Leang SK, Cui L, Deng YM, Phuah SP, et al. Increased detection in Australia and Singapore of a novel influenza $A\left(\mathrm{H}_{1} \mathrm{~N}_{1}\right)_{2009}$ variant with reduced oseltamivir and zanamivir sensitivity due to a $247 \mathrm{~N}$ neuraminidase mutation. Euro Surveill. 2011;16(23):19884.PMID: 21679678

\section{License and copyright}

This is an open-access article distributed under the terms of the Creative Commons Attribution (CC BY 4.0) Licence. You may share and adapt the material, but must give appropriate credit to the source, provide a link to the licence, and indicate if changes were made.

This article is copyright of the authors, 2016. 